\title{
The Ruse of Reading The Postcolonial Literary Marketplace and the Novels of Gina Apostol
}

\section{Ma. Gabriela P. Martin}

Ateneo de Manila University

\section{Abstract}

This paper explores the politics of reading in the novelistic production of Gina Apostol in relation to Sarah Brouillette's analysis of the postcolonial literary marketplace, Timothy Brennan's critique of cosmopolitanism, and Gayatri Chakravorty Spivak's tracking of the native informant in postcolonial discourse. In Brouillette's work, postcolonial writers, unlike the Romantic author who disavows commercial popularity, are aware of the commodification of their work and interact with it, either through resistance or complicity. Cosmopolitanism for Brennan denotes an unequal flow of intellectual commodities between center and periphery instantiated in the consciousness of the migrant writer valorized in "international book markets because of their authentic native attachment to a specific Third World locale" ("Cosmopolitans and Celebrities" 3). Lastly, the native informant, in Spivak's A Critique of Postcolonial Reason, is a postcolonial subject whose self-representation projects the ascendancy of liberal Western discourse while authenticating a homogenized identity for the 'Other'.

\section{Keywords}

postcolonial, literary marketplace, authorial strategy, cosmopolitanism, native informant 
To say that reading occupies pride of place in Gina Apostol's literary production would be an understatement. Not only are the protagonists in her four novels readers: Primi Peregrino in Bibliolepsy (1997), the titular character in The Revolution According to Raymundo Mata (2009, 2021), Soledad Soliman in Gun Dealer's Daughter: A Novel (2012), and Chiara Brasi/Mimi Magsalin in Insurrecto: A Novel (2018) but the stories themselves are metafictions that capitalize on reading as a practice and its theoretical contexts. In "Reading and Writing: Some Notes on the Author's Patrimony by Estrella Espejo," a fictional paratext in The Revolution According to Raymundo Mata, for instance, Apostol reworks Benedict Anderson's key observation that Rizal's realist perspective in Noli Me Tangere summons an 'imagined community' in the minds of its readers (27): "The Philippines may be the only country whose war of independence begins with a novel (and a first novel at that)-Rizal's Noli Me Tangere ('Touch-Me-Not'). Our notion of freedom began with fiction, which may explain why it remains an illusion" ("The Revolution" 25). In the same section, Apostol doubling as Espejo, the fictional editor of Mata's book/journal, explains the exigency of the word in understanding the 1898 Philippine Revolution:

By 1896 readers were risking their lives all over the place to smuggle pamphlets and decode anagrams of heroic names. Membership to the Katipunan rose dramatically with the publication of the first (and last) distributed issue of a newsletter, Kalayaan. Histories of the war refer constantly to memos to the warfront, distributed decalogues, intercepted letters, confiscated libraries. It is said that unread peasants gained revolutionary passion via pasyon, a narration (25).

Textuality is also a central conceit in Gun Dealer's Daughter: A Novel. In the story, Soledad, the main character, is suffering from amnesia and words, according to her doctor, are crucial to her recovery: "Language plays its part, the doctors say: above all, words are symptoms. I must be alert. Even one's vocabulary could be a crime" (Gun Dealer's Daughter 18).

In the first section of this essay, I examine Apostol's preoccupation with reading as an extension of what Sarah Brouillete, in Postcolonial Writers in 
the Global Literary Marketplace, points out as the strategic self-consciousness of the postcolonial author who is actively involved in the reception of his/ her works by metropolitan First World audiences. Reading in this context is a vehicle for cosmopolitan and intercultural values whose cultural capital is consecrated by an international reading public. In the second section, I compare scenes of reading in the postcolonial analyses of Naipaul's A House for Mr Biswas and Dangaremba's Nervous Conditions with Apostol's novels. Lastly, I argue that Apostol's fictocritical strategy offers reading as an elaborate ruse for foreclosing the text from its social and political logic, which allows the text to do the work of "self-writing."

\section{Reading Publics}

In her book, Brouillette claims that postcolonial field had become an industry, echoing and expanding on Graham Huggan's seminal insights on postcolonialism's similarity with tourism in his book The Postcolonial Exotic: Marketing the Margins (2001). For both scholars, postcolonial literature had undergone "industrial commodification that serves the interests of certain privileged audiences; the 'postcolonial field of production' turns out translated products for metropolitan consumers in places like London and New York" (Brouillette 15). Huggan claims that postcolonial literature written for a metropolitan audience tends to privilege certain representations and strategies where "difference is appreciated, but only in the terms of the beholder [while] diversity is translated and given a reassuringly familiar aesthetic cast" (qtd. in Brouillette 16). This tendency, for Huggan, is the fate of the postcolonial in the globalization of commodity culture that aestheticizes cultural difference and makes it available for mass consumption; the code for such aestheticized difference is the exotic, an "aesthetic perception... which renders people, objects and places strange even as it domesticates them, and which effectively manufactures otherness even as it claims to surrender to its immanent mystery" (13). Although Brouillette agrees with Huggan's description of postcolonialism as a touristic industry, her view grants more autonomy to the author who employs "otherness" strategically and is willing to market "authorial self-consciousness" through several literary strategies which he/ 
she negotiates with the reader (7). Unlike Huggan, Brouillette is more interested in examining how postcolonial authors manifest a self-awareness of the potential reception of their work by anticipating and responding to it in their writing. In the chapter on Derek Walcott, for example, Brouillette identifies the persona in his poem collection The Fortunate Traveller as the poet himself, a "bureaucrat, a functionary of the neocolonial world... an intermediary between the Third World's citizens and Northern institutions of geopolitical power" (34), underscoring an inclination of migrant postcolonial authors published by Anglo-American publishers to write themselves in their novels as a means of exercising the author function.

From the outset, Apostol's postmodern novels confirm Brouillette's observations about highly-marketable postcolonial literature in the First World metropolis: "it is English-language fiction; it is relatively 'sophisticated' or 'complex' and often anti-realist... it uses a language of exile, hybridity, and 'mongrel' subjectivity" (61). Brouillette's claim that postcolonial writers employ self-conscious strategies in their works is evident in the novelistic world of Raymundo Mata and Gun Dealer's Daughter. A cursory reading of Apostol's interviews and blog essays is enough to establish a correspondence between main characters in both novels and the author herself. Moreover, Apostol has written copiously about her obsession with books and how her writing pays homage to her favorite authors, among them, Flaubert, Borges, Nabokov, and Barth. Note, for instance, the parallels between author and characters: Apostol's frequent visits to the British Council in Manila which she mentioned in her blogs ("On Finishing a Novel: Thoughts on Writing About Philippine History"), is a hobby of Fernando, a character in Bibliolepsy, her first novel, and Sol in Gun Dealer's. There are references to libraries in The Revolution According to Raymundo Mata [e.g., "Andres Bonifacio's library" (47), “Rizal's library” (97), “Crisostomo Ibarra’s library” (182)], which suggests that the Philippine Revolution was an effect of reading, a claim that Apostol reiterated on several blogs and interviews. In "Reading and Writing: Some Notes on the Author's Patrimony," for instance, Espejo states that "[a] distinctive quality of this war was its reliance on reading-literacy was the charming obsession of many a revolutionary" (24). Espejo narrates, in the 
same section: "By 1896 readers were risking their lives all over the place to smuggle pamphlets and decode anagrams of heroic names.... It is a truism that our revolution existed-and lives on-as a text" (25).

Moreover, Apostol is known to provide readings or interpretations of her novels which reference a number of literary theories. This strategy, which is consistent with Apostol's self-authorization and self-reflexivity, allows her to manage and police the reception of her works. Postcolonial theory, for example, from which Apostol launches her notions of doubleness, multiplicity, hybridity, functions as both paratext and master trope in Apostol's novels, essays, and interviews. She chides Mark O'Connell, who wrote a review of two new books on Borges in The New Yorker, for taking Borges' statement that he is "not politically minded" at face value: "[a]nd like a gullible reader of Pierre Menard's Don Quixote, O'Connell falls for Borges's wit, his “double act." Taking offense at O'Connell's statement and casting her lot with Borges, while labelling O’ Connell a First World writer, she refutes his point by recounting a personal history:

Having grown up under a dictatorship, beset by the local scars of the history of colonization, I know my debt to Borges. I learn from him as an artist but I also read him as a luminous thinker about the politics and problems of the so-called Third World.... writers in The New Yorker... might not have the experience that Borges and I have-the postcolonial experience of that 'divided self', that 'ontological double act" ("Borges, Politics, and the Postcolonial").

Elsewhere in the article, she calls Borges's essay "The Argentine Writer and Tradition" ... "a classic in deconstructive political thought" while calling Menard, the author-double of Cervantes in Borges's story, "Pierre Menard, Author of the Quixote," a "commentary on the postcolonial condition." Apostol defines "postcolonial" as mode of deconstruction: "More practically, I read Jorge Luis Borges in this postcolonial, deconstructive way... I read Poe and detective stories and Nabokov in this way too-in a postcolonial, deconstructive way" ("Advice to Writers”). 
Another authorial apparatus that Apostol deploys in her novels is the paratext, defined by Gerard Genette as a device which "enables a text to become a book and to be offered as such to its readers, and more generally to the public" (1). It mediates "between the inside and the outside, a zone without any hard and fast boundary on either the inward side (turned toward the text) or the outward side (turned towards the world's discourse about the text)" (2). Paratextual elements can be divided into peritexts, those that appear within the book itself (e.g., title, preface, dedication, notes, epilogue), and epitexts, which refers to information about the book gleaned from author interviews, recommendations, publisher's statements, author's blog, and other promotional strategies. The fictional peritexts in The Revolution-an editor's preface, a translator's note, an abecedary, an afterword, an epitaph, a translator's postcard and references-reinforce Apostol's control over the story while limiting its interpretation. As Genette notes the paratext is "an influence on the public, an influence that-whether well or poorly understood and achieved-is at the service of a better reception for the text and a more pertinent reading of it (more pertinent of course, in the eyes of the author and his allies)" (1). That peritexts represent the interests of the author is evident, for example, in Apostol's approval of a researcher/blogger from Filipiniana.net for engaging the aforementioned peritexts in The Revolution in the correct way: "This article researches facts in history related to details in the novel... While not ingenious, it is earnest, and I enjoyed looking at how the researcher figured out some of the novel's puzzle out. There are so many pieces of the jigsaw puzzle in this layered novel that it is satisfying when a person at least figures out even one corner of the complex piece... the novel, if figured out completely (my emphasis), is meant to shed light on multiple resonances among and between history, reading, language and art with the revolutionary period of the Philippines" ("Nice Job of Research"). Apostol, as the rest of this essay will demonstrate, equally relies on epitexts to promote the 'correct reading' of her novels. In this sense, paratexts are tools of marketing literature and circumscribing its literary value.

It is important to note that Apostol tends to reference "postcolonial" in a manner that preempts a candid reading of her novels and, more 
curiously, as a catch-all phrase to describe her experience that confers a ready-made significance and authenticity in her writing. In this context, Apostol's novels are fictocritical: they merge self-writing, fiction, and criticism (Robb 5-7). The individualized/experiential meanings and frequent incantation of "postcolonial" indicate an authorial self-consciousness that caters to the reading competence of metropolitan audiences in the global North. In "The Novel and Technologies of Empire: A Conversation with Gina Apostol," an interview conducted by Paul Nadal, Apostol admits that Insurrecto, her fourth novel and the second one published in the U.S., was based on a draft for The Unintended. She explains: "I think Duterte made the novel urgent in some way. Duterte in power created a demand to figure out how to include the current political situation in a novel. I wasn't going to include it in Insurrecto, because I already had a draft. But my first readers, including editors, were curious about Duterte's possible place in the story I had written" (Nadal). As this suggests, Anglo-American publishing industries exercise a significant influence in determining the content, which validates Brouillette's observation that postcolonial authors published in the U.S. are more receptive to metropolitan tastes, and following Bourdieu, that authorship in the "social production of literature often translates into literature itself (2).

In a response to an article on Gun Dealer's Daughter in Manila Review, she denounces the shortsightedness of the review which she claims was oblivious to the artistic status of her novel and instead reduced it to "a social studies thesis"; she writes: "I did not recognize my novel at all-didn't hear language, tropes, ironies, complexities-a non-reading of art" ("Reading Novels: A Novelist's View"). Although she issues a disclaimer at the beginning that her ideas are only those of a provisional reader, she calls the Manila Review article a "misreading" since it was silent about the intended connection between character (Sol) and reader. She ends the essay by emphasizing her intention:

When you do not examine the crucial ways the reader is implicated in a self-referential text (and most texts, once you read them closely, are self-referential), which involves the tropes of reading and writing, in which the crisis of self-discovery lies in the ruses of language, and in this case, in partic- 
ular the rapacious English language, the reader might be led to a meager, shallow reading.... In this novel, and in other self-referential novels that deliberately involve the reader in language games, these novels that involve acts of reading and writing in its tropes are also directly addressing community-the imagined community of novel reader, novel, and protagonist, that needs to be imagined by the essayist ("Reading Novels: A Novelist's View").

In contrast, there are reviews of Gun Dealer's that are more reflective of metropolitan tastes and preferences which Apostol approves of and has cited on her blog. These reviews consider Apostol's use of style commendable for the pleasures it affords the reader. One is by Merry Gangemi, host of WomanStirred, a radio program in Plainfield, Vermont, whom Apostol considers to be "an intelligent reader" for having noticed "the incidence of insects, repetition of heat and decay, and the book's language games" and their priority in Gun Dealer's ("Listen to Woman-Stirred Radio"). Brian Collins in the Los Angeles Review of Books comments on a vivid passage in the book:

as deft a sketch as something from Fitzgerald and the happy accident of the able storyteller is contrived with so much grace than in too many new books, where narrators sound like writers no matter what their fictive place in life; Soledad's verbal intensity we grasp as that of a bookish only child with a cosmopolitan upbringing. Apostol even allows her to overwrite here and there, to slip into a precious or self-indulgent style, sharpening our image of Soledad as a stunted character. (For a sense of Apostol's own impressive style range see also her first novel Bibliolepsy, already a kind of contemporary classic back home in the Philippines, though now out of print. Soon, I would think, some alert publisher will bring this book out in the US).

Apostol included Collins's review in her blog and captioned it: "a stunningly smart review” (“Empire at the End of Time': a Stunningly Smart Review"). In the same blog, Apostol mentions a "lovely review" of the novel by Kerry McHugh at Entomology of a Bookworm: Sol's "telling and retelling and editing and tweaking of her own history feels disjointed in the opening chapters, but ultimately proves to be one of the most successful aspects of Apostol's creations; the technique invites readers into the very core of 
Sol's experiences, accompanying her on her journey of self-understanding... self-acceptance” (“Lovely Review”).

Apostol's U.S. publishers are similarly invested. Denise Scarfi, Apostol's editor at W.W. Norton, the US publisher of Gun-Dealer's Daughter recalls dropping everything to read a draft of the novel after a literary agent's prodding, who called it an "obdurately literate tale of rebellion and romance, adolescence and assassins." In Scarfi's interview with Apostol for Bookslut, the first part of which is published in Apostol's blog, the former lauds the latter for prioritizing her craft, calling Apostol a writer "who thinks so deeply and intelligently about her craft, and who writes out of pure enjoyment. It is a testament to her skill and sense of humor that she'd managed to have fun (and to create a fun reading experience) writing about Sol, a daughter of arms dealers..." The novel, Scarfi claims, is one of "infinite satisfactions - a coming of age tale, a love story, an amnesiac thriller, a revolutionary potboiler." (“Bookslut Interview”). Interestingly, Scarfi would also drop a comment in a blog by Brian L. Belen (Brain Drain comments section) that reviewed the same novel before Norton published it. Refuting Belen's remark that it may "not be accessible to those that don't know much about the Philippines" since "[i] t's a book about the Philippines written with a Filipino audience in mind," Scarfi replied: “As Gina's Irish-Italian editor, I will argue that this book absolutely can be understood and enjoyed by non-Filipinos! Her ability to allude to Filipino history and politics with subtlety (my emphasis) is what makes this such a compelling read, and smart readers will be able to put the pieces" (Belen). The fact that this brief exchange about Apostol's novel revolves around the novel's ideal reader-Filipinos or non-Filipinos-is instructive of how the "imagined readership," which the author anticipates and influences as part of his/her self-conscious strategies (Brouillette 6), indexes the value of the work. Scarfi's comment, tellingly, attributes the readability of Gun Dealer's to its muted references to actual, concrete situations and moments that motivated Philippine history. Belen's and Scarfi's comments imply a distinction between the local and international reception of the novel. It is unsurprising thus that this valorization of narrative style and construction 
is the central idea in Apostol's introduction in the US edition of Raymundo Mata.

The review of Christian Benitez, a Filipino critic, of Insurrecto is one of the few that considers it from the perspective of a Filipino audience. Overall, Benitez finds the novel's "metaphoric strategy" inadequate:

As a novel that attempts to "show us the dark heart of a forgotten war that would shape the next century of Philippine and American history," what Insurrecto ultimately offers is a performance: the aforementioned war critically takes place less within the competing narratives of the novel, than in the struggle of reading the text itself (my emphasis), given its temporal and metaphoric strategies that disrupts the form, especially in its speciation in the Philippine imagination. And that such disruptions come from Apostol, a writer currently based in the United States, only doubles the violence of the Philippine disappearance to a Filipino reader: despite the desire to foreground an often neglected moment in Philippine history, the novel induces the same neglect through its impressionistic metaphorizations and aphasiac techniques, dangerously repeating to the reader the phenomenon of forgetting (112-113).

Benitez's review is informed by the material specificities of a Filipino reader, one whose interests are not limited to academic tastes, while negating the idea that mere complex telling, which involve disruptions of the form, can offset official narratives which erased or othered the Filipino in Philippine history. The idea that "in multiplicity is truth," the title of Laurel Fantauzzo's interview of Apostol which also forms the logic of Apostol's statements about The Revolution and Insurrecto in other epitexts, begs the question of which historical process or whose experience is represented in the range of perspectives that "multiplicity" implies. E. San Juan has analyzed this condition in Beyond Postcolonial Theory and deplores that postcoloniality has become inseparable from postmodernism: "[b]ecause postcolonial critics are heavily invested in the complicitous critique offered by postmodernism via irony, allegory, and self-reflexive tropes of doubleness, they reduce everything to metanarratives of contingency and indeterminacy" and this view, he asserts, is shortsighted for it "confuses self-misrecognizing mastery of difference with empowerment of citizens" (24). Apostol's defense of postmodern 
tropes tends to make a cult out of difference while eliding a central consideration of postcolonial theory which is "who speaks and for whom?" and this is, in a sense, the same problematic that Brouillette's addresses in her study of the postcolonial literary marketplace.

The relevance of textual prolixity is also called into question in Myra Garces-Bascal's review of Insurrecto in Gathering Books. Bascal finds the complexity of the novel off-putting, particularly the ordering of the chapters and her sentiments coincide with Benitez's and San Juan's:

I do wonder at the target audience of the novel, or even if there is one, or if the question is moot and academic. The reason I even thought of it is my inner wondering as to whether the story is reaching its intended audience in a way that will move them, or at least make them think deeply about who they are and what it means at a time when the islands of the country are disappearing and bargained off to the highest bidder, where silence and difference are conjoined twins allowing evil to proliferate with immunity (Garces-Bascal).

The reviews in the preceding discussions indicate a tension between national and metropolitan reception that Brouillette considers exemplary of the role of First World literary markets in promoting the postcolonial novel. For Brouillette, whose view of the literary field reworks Pierre Bourdieu's understanding of the term as a site of conflict between forces of autonomy and heteronomy, "[a]ttending to the changing nature of current publishing, and to the position of postcolonial authors within literary markets, thus assumes a compelling relevance for meaningful interpretative practice” (1). This suggests that the commodification of the literary, in the postcolonial marketplace, has allowed the author to exercise some power in responding to the expectations of her audience while finding a niche in the book market. And this process, as demonstrated, is one that Apostol fully participates in. Brouillette points out that writers are complicit in this process: "authors then act as consumers of their own images as they react to their own personae in their literary works, often through attempts at theorizing the process itself, whether thought of as the communication circuit, the field of cultural production, or... the field of postcolonial production" (3). 


\section{Postcolonial scenes of reading}

The connection between reading and postcoloniality has been explored in other novels and critical work on them although with aims that are political, resistant, and subversive. In "The Formalist Genesis of 'Postcolonial' Reading: Brathwaithe, Bhabha, and A House for Mr. Biswas," William Ghosh traces the import of reading in postcolonial studies by attending to the novel's own emphasis on form and relating it to two different receptions of Naipaul's novel in a meaningful genealogy. Ghosh analyzes the scene of reading in the novel where Mr. Biswas, a Hindu-Indian in Trinidad and Tobago, is moved by the "wish-fulfillment" novels of Hall Caine and Marie Corelli only to realize that the "intoxicating world" and the "[d] escriptions of weather and landscape," which caught his fancy, are discontinuous with his own social reality. The moment is narrated by Naipaul:

[h] e stayed in the back trace and read Samuel Smiles. He had bought one of his books in the belief that it was a novel and had become an addict. Samuel Smile was as romantic and satisfying as any novelist, and Mr Biswas saw himself in many Samuel Smiles heroes: he was young, he was poor, and he fancied he was struggling. But there always a came a point when resemblance ceased (Naipaul, qtd. in Ghosh 769).

Similar to Apostol's recruiting of literary authors and works in her novels, Naipaul references other writers in his novels (Charles Dickens, Mark Twain, Guy de Maupassant, Walter Scott, and Nikolai Gogol) but as Ghosh points out, Naipaul brings up these authors in A House for Mr Biswas to draw attention to the "historicity of the novel form," its European provenance, and "how it had functioned for colonial Caribbean readers" (769). Moreover, Naipaul's curiosity about the novel form allows him to address its "disciplinary social functions" (772). Ghosh proceeds to another scene of reading, this time demonstrated by a young Homi Bhabha. In two early essays ("Representation and the Colonial Text" and "The World and the Home") Bhabha offers a reading of Naipaul's novel, which Ghosh notes, would form the core of Bhabha's more widely-read Location of Culture: 
[w]orking on A House for Mr Biswas I found that I couldn't fit the political, chronological, or cultural experiences of that text into the traditions of Anglo-American liberal novel criticism. The sovereignty of the concept of character... and the practical ethics of individual freedom bore little resemblance to the overdetermined, unaccustomed postcolonial figure of $\mathrm{Mr}$ Biswas ("The World and the Home," qtd. in Ghosh 776).

Naipaul and Bhabha, Ghosh argues, are postcolonial readers in that their awareness of the novel as a European form has "forced [them] into a dialogue with a literary tradition that is neither wholly native to them nor wholly alien" (776). In contrast, the comparisons in Apostol's novels, whether explicit or implicit, defines postcolonial agency as a demonstration of postmodern readings (e.g., doubleness, multiplicity).

In "Differential Publics-Reading (in) the Postcolonial Novel," Elleke Boehmer analyzes the role of reading in Tsitsi Dangaremba's Nervous Conditions, Manju Kapur's Difficult Daughters, and Chimamanda Ngozi Adichie's Half of a Yellow Sun. Boehmer claims that the three novels stage scenes of postcolonial reading which speaks to and renews "transnational and cosmopolitan values" (1). Scenes of reading in these novels problematize the relationship between the telling and the told: the told are the texts sampled by the main character ("what a text has read"), a reader, while telling denotes the narrational mode that constructs the relationship between the author/narrator, characters, and reader (12-13). Here Boehmer borrows Althusser's concept of interpellation as a process that allows texts to "hail" and address readers. Interpellation explains "how the postcolonial reader is invited by or invoked within the text, either as a character, or through the text, as its reader" (13). Boehmer's study is relevant primarily for its identification of significant dialogic relationships that accrue when the text that is read is situated differently from its reader and serves as a useful counterpoint to Apostol's novelistic deployment of reading as aesthetic structure even as Boehmer refracts the text through a cosmopolitan lens. Dangaremba's Nervous Conditions, which takes place in Southern Rhodesia in the 1970s calls attention to the conflict between the experience of English-educated Nyasha and Tambu and the books that they're required to read in mission school. 
Boehmer refers to a paradigmatic moment of reading in the novel when the adolescent Nyasha reads D.H. Lawrence's Lady Chatterley's Lover, which "calls up both her rebelliousness and her privilege as a character, a child of the colonial middle class in Zimbabwe (then Rhodesia)" (13). The mode of the telling positions Lawrence's novel athwart and alongside Dangaremba's novel. Reading in the three novels, Boehmer claims, is integral to the characters' coming to consciousness and, as such, they problematize reading's inextricability with colonial experience and its potential in fostering cosmopolitan belonging. Boehmer elaborates:

[r] eading understood in this way, as involving translocal, transnational, and other cross-border modes of identification, including other publics different from one's own, can also be seen to activate cosmopolitan sympathies (14).

She expounds: "[r]eading does not involve merely the application or imposition of a meaning or framework upon a piece of writing. Rather, reading is taken to involve imaginative and cognitive interaction with that writing, or the repeated application of inferential procedures to it" (17).

The focus of both essays on reading and its concrete historical situations gesture toward a relevant postcolonial problematic, one that enacts a "contrapuntal" reading of texts, which Said describes as "a simultaneous awareness both of the metropolitan history that is narrated and of those other histories against which (and together with which) the dominating discourse acts" (51). Naipaul's and Dangaremba's novels are inquiries on the role of literature in furthering an awareness of difference produced by the disjunction between the colonized's socio-historical reality as it shapes cultural knowledge and practice and literary forms and their interpretations, which are part and parcel of colonial legacies (e.g., education). In contrast, reading in Apostol's novels conscripts and elevates an aesthetic lineage, a universal literature dislocated from the historical exigencies of colonial experience. As Benitez points out in his review of Insurrecto, Apostol's reliance on metaphor conflates the act of reading with the act of addressing gaps in Philippine-American history as if the struggle to read a postmodern text 
like Insurrecto or The Revolution is a representation of the Filipinos' untold experience in the Philippine-American war or the Revolution of 1898.

If, for Boehmer, cosmopolitanism underpins the potential of reading in its capacity to imagine alternative solidarities, Apostol, represents its nominal value. This nominal sense of cosmopolitanism inheres in a dynamic between center and periphery where the latter functions as a relay for the former's values which is often masked as hybridity while "sublimating differences on grounds of understanding by way of a motive to export ideological products made to the measure of the world of saleable things" ("Cosmo-Theory" 660). Brennan argues further that the cosmopolitan figure that emerges from this context "expands his or her sensitivities toward the world while exporting a self-confident locality for consumption as the world" (660). Thus, despite Apostol's valiant statements about Rizal, Noli Me Tangere, and the Philippine Revolution; these references and allusions, which she dryly calls "facts," are merely pressed into the service of the writer's mastery of Borgesian doubleness ("My Borgesian Rizal") and the aesthetic "involution" that characterizes Nabokov's Pale Fire (Appel qtd. in McGurl 9) among others. These comparisons only signpost a series of narrative mise-en-abymes which seem to be the more important consideration in Apostol's novels. A number of comparisons in The Revolution According to Raymundo Mata, for instance, posit a genealogy or an encounter between the local and international. In footnote 84, Diwata Drake, a caricature of a Lacanian critic, seizes on the likelihood that Raymundo had read Voltaire's Candide:

I note the translator's disclaimer above... Inexplicably, the manuscript [Raymundo's journal entry no. 5] inserts Voltaire's Candide word for word, except for substitutions of random names later in the manuscript... It would have been impossible for Raymundo, a sensitive boy in late nineteenth-century Philippines, not to see the parallels to his country's condition in the anticlerical satire he's writing down word for word; just as it is impossible for Estrella not to read Raymundo in the paragraphs from Voltaire... Thus, despite herself, Estrella's 'misreadings,' her anachronisms, are perhaps accurate (The Revolution 81-82). 
Apart from Voltaire, Apostol enlists Cervantes, Dumas, Baudelaire, The Gulag Archipelago, Dante's Hell, Eugene Sue's Mysteries of Paris, Tolstoy, Charon, Prometheus, Homer, the Cyclops, and Oedipus to frame other characters and moments in the novel. These references to foreign authors and literary works enact a comparativism or revaluation not dissimilar from the consecration of national authors to what Pascale Casanova describes as "world literary space" $(87,109)$. This strategy, which instrumentalizes a literary cosmopolitanism, is also responsible for the global reach of the novel. Apostol compares Raymundo Mata's blindness, for instance, to two literary characters': "I edged beyond the calesa paths, across palay harvests, sapa and streams. I ranged like the Cyclops and roved more or less like threelegged Oedipus; I did not sing like Homer" (238). The comparisons, whose logic is unmotivated by the narrative-it is not established, for instance, how Mata's character overlaps with Oedipus or the Cyclops apart from their visual impairment-effects a universalization of a figure whose perspective allegedly offers a focalization of the Philippine revolution.

Brouillette considers Casanova's work to be a timely modification of Bourdieu's analysis of cultural capital and how it emerges from autonomous social space, which is brought about by the broad commercialization of the literary field, especially postcolonial literature: "the local writer enters the global field not to access the more legitimate cultural capital attached to modernist aesthetics, but out of a desire to achieve global celebrity" (80). Here local writers are consecrated in the world republic of letters, which operates on "the opposition between a capital, on the one hand, and peripheral dependencies whose relationship to this center is defined by their aesthetic distance from it," thereby assuming recognition, a kind of world-readability by ignoring national concerns while supporting the notion that literature is "pure, free, and universal" as opposed to its emerging from "political fiat, interest, or prejudice" (Casanova 12). This tendency accounts for the cosmopolitan undergirding of Apostol's novels, which translates the national to a global literary paradigm, to speak to an international audience. Moreover, the structure of the narrative itself, appropriated from Borges' and Nabokov's 
postmodernist aesthetic, allows Apostol to address metropolitan audiences in the global North. As Casanova claims:

the writers who seek greater freedom for their work are those who know the laws of literary space and who make use of them in trying to subvert the dominant norms of their respective national fields. The autonomous pole of the world space is therefore essential to its very constitution, which is to say to its littérisation and its gradual denationalization: not only does the center supply theoretical and aesthetic models to writers on the periphery; its publishing networks and critical functions jointly strengthen the fabric of universal literature (109).

Apostol's novels are thus intelligible to US publishers because of how they are written, more than the story that they tell. Sabina Murray's description of Raymundo Mata in her interview with Apostol in LitHub, for instance, re-packages the novel's relevance by capitalizing on its lessons for the Trump era:

The Revolution According to Raymundo Mata... is a marvel of structure, history, voice, and humor... This rich comedy grows out of a tradition launched by Borges, an influence readily acknowledged (a Pedro Ménårdsz pops up in the footnotes), but also calls to mind the rollicking humor of Flann O'Brien's At Swim-Two-Birds in its textual meddling, using the disruption of order as an organizing principle. In fact, the book can be seen as an exploration of the comic: the compulsive punning of the Filipino, the wry conceits of the critic, Apostol's joyful wit in the deployment of a stunning array of figures of speech. At its core, the book examines the revolution that wrenched the Philippines from the stranglehold of Spain, only to thrust the nation into the rapacious embrace of the United States. First published in 2009, Apostol took advantage of this new American edition to further explore its themes of insurrection, media falsehood, and the splintering of reality under the force of differing opinion as she lived in Trump's America. Raymundo Mata, despite its focus on an invented Filipino hero, should be required reading as we navigate these times (Murray).

Of the two levels of reading specified in Boehmer's essay, Apostol is clearly more interested in the telling not in the potential dialogue between the two, which Boehmer considers as a relevant postcolonial problematic. In 
their book Reading Across Worlds: Transnational Book Groups and the Reception of Difference, Bethan Benwell and James Procter, citing John Guillory's study "The Ethical Practice of Modernity: The Example of Reading," outlines the distinctions between lay and professional reading, a problematic related to the role of reading in literary studies, especially postcolonial critique (see Lazarus' “The Politics of Postcolonial Modernism”). Guillory defines professional reading as "a kind of work... a disciplinary activity, that is governed by conventions or interpretations... is vigilant, and stands back from the experience of pleasure, not in order to cancel out this pleasure, but in order necessarily to be wary of it" (qtd. in Benwell and Procter 21). Lay reading, in contrast, is pleasurable and solitary, which encourages "self-absorption over critical consciousness" (21). Professional reading is an attention to the text that subscribes to the "trope of complexity," which recalls Timothy Brennan's and Sarah Brouillette's discussions of the concept in At Home in the World: Cosmopolitanism Now and Postcolonial Writers in the Literary Marketplace, respectively. Benwell and Procter also reference Tony Bennet's observations about professional reading which brings to mind Apostol's prerogative: a "reading [that] seeks to clear a space for itself and to displace the cultural power of prevailing readings by producing, in its construction of the text itself, the criteria of validity in relation to which other readings can be found wanting" (qtd. in Benwell and Procter 21). Bennett's point lays bare the logic of Apostol's prescriptions about reading and their indispensability for postcolonial work. This imperative is often articulated as a call for smarter readers which is made explicit in her interview in Fiction Advocate, for instance. The question as to whether the postmodern structure of her novel might convince readers that Insurrecto is only fiction, Apostol's replies with "No-those readers need to get smarter" (Stack) and proceeds to a reiteration of her oft-quoted observations about the constructed nature of history and reality. Another instance is her justification for her writing in the Author's Note on the US edition of The Revolution According to Raymundo Mata: "For me, a powerful reason to write novels like these is that their construction matches my sense of reality [my emphasis]. A colonized country is the overt result of various others shaping its sense of self. The novel's 
multiple voice, which refracts, realigns, repositions texts and viewpoints from awry angles, ruptured plots, confused tongues, and an almost heedless anachronistic sense of the past, is for me a potent way to fathom and portray the unfinished 'reality' of such a nation." Recurring in this piece and her other essays and interviews is the idea of the author's pleasure projected onto the reader. In her riposte to Manila Review's reading of Gun Dealer's Daughter, Apostol writes: "My editor says that the reason she picked up this novel and fought for it at Norton was because of its language. The wordplay was funny she said. The pleasure of the text. For me, the work of language is where a novel's eroticism, pleasure, lies" ("Reading Novels"). Pleasure, elsewhere in the same essay, is mentioned when she explains the connection that binds reader and narrator:

[p]art of the problem of writing in English in the Philippines is that one might say that English is a sign of trauma: it inscribes our colonized self in our everyday lives, just as Rizal noted the same for Spanish in his time. English, just as Simoun noted about Spanish, touches on a divide. Right now, you can succeed without English, like Erap (or at least the myth of Erap), but our system makes it difficult. In the early American period, English was both the rape and redemption of the middle classes. Knowledge of it allowed the middle classes to expand, so it democratized even as it drove a wedge: it created marked division. So it's useful to note that this partnership between the reader and the narrator in this novel is pleasure, or at least, proficiency in English. Language is the erotic tie between narrator and reader ("Reading Novels").

To be sure, what Apostol refers to as "proficiency in English" is not commensurate to the pleasure of the reader, as Guillory refers to it in his essay. In his review of The Revolution, Guzman observes the same impasse. He notes that while the novel's "tireless pastiching" is "exhilarating," he admits that it "is easier to admire than to enjoy" (281). Its humor, he adds, dependent on slips of the tongue and satire, can be contrived: "[u]nfortunately, satire is not the most comedic form, given that it is more interested in teaching the reader a lesson than in making him or her laugh; in effect, a succession of satires 
packaged in zingy one-liners often sounds less like humor than items in a syllabus" (281).

That Apostol privileges the telling and regards it as a tool of postcolonial critique is suggested in a number of her essays, but it is most evident in her recent interview published in Fiction Advocate. Here she claims that Borgesian and Nabokovian narrative structures, which produce "the destabilizing of reality through mediated stories-are very rich for postcolonial work" (Stack). These two, narration and postcolonial writing, she elaborates, produce something both "politically coherent-and fun." Her advantage, she continues, is having grown up in "the hyper-hybrid, mixed-world of the Filipino... I hold the advantage of multiple-world-the Western art-worlds of Nabokov, the unbearably multiple-worlds of the Warays... I make that multiplicity central in Mata and Insurrecto: so that the novel's form is in itself also political and historical commentary" (Stack).

\section{Cultural Capital and Self-Writing}

Certainly, postcolonial studies had professionalized a kind of reading, perhaps more than any other critical theory, and this is understandable given literature's role in colonialism. In fact, the complicity between the two has been the subject of studies done by Frantz Fanon, Edward Said, Homi Bhabha, and Gayatri Spivak. A kind of reading was ordained by Ashcroft, Griffiths, and Tiffin in their book Post-Colonial Studies: Key Concepts as postcolonial:

A way of reading texts of both metropolitan and colonial cultures to draw deliberate attention to the profound and inescapable efforts of colonization on literary production; anthropological accounts; historical records; administrative and scientific writing. It is a form of deconstruction most usually applied to works emanating from the colonizers (but may be applied to the works of the colonized) which demonstrates the extent to which the text contradicts its own assumptions (civilization, justice, aesthetics, sensibility, race) and reveals its (often unwitting) colonialist ideologies and processes (192).

Apart from postcolonial studies, reading has gained currency in other fields in literary and cultural studies. Another work that signals an increase 
in reading's cultural capital is Martin Joseph Ponce's book Beyond the Nation: Diasporic Filipino Literature and Queer Reading. Ponce considers Raymundo Mata exemplary of a "diasporic" and "queer" reading which, he claims, accurately describes Filipino literature in the United States in its status as a "dispersed, coreless tradition whose relation to conventional political and social histories has invariably been oblique and ex-centric to the latter's normalizing dictates" (2). This interrogation of that particular literary history, Ponce explains, does not flatten difference but "[pursues] instead interpretations that underscore rather than underplay the literatures peculiarities in ways that render inadequate cultural nationalist models of reading and that respect the "wild heterogeneity" of this literary archive" (3). This ex-centricity, he notes, is what Raymundo Mata exhibits. Its metafictional reconstruction of the 1898 Philippine Revolution reflects the central themes of his study, namely "the politics of linguistic multiplicity, address, and audience; the critique of U.S. imperialism; the relation between sexuality/desire and nationalist affect; and the need to cast an "awry lens" at the pieties of the past” (224).

Ponce concludes his analysis of the novel by pointing to its "un-oneing" of the ideas of "reading, revolution, and resurrection," a "universalist gesture" which Apostol closes the novel with. He writes:

... $\mathrm{t}]$ his novel in many ways is about recovery. The recovery of a text, a body; the recovery of a hero, a history; the recovery of a country, a past.... The power of Rizal, and the power of our history, is that these genii are inexhaustible: we must be glad for the patently 'unfinished' and infuriating history that we have-in this way, it seems, Filipinos must represent the complexity of everyone's incomplete and indeterminate selves, and our endless, surprising resurrections (293).

Despite the different discourse (the queering of reading), that Ponce tackles in his book, his interpretation of Apostol's novel resonates with its transnational reception. Both regard her use of narrative constructionism as productive of contestatory readings; thus the "awry lens" is enough and is a sign of the political. Ponce closes his commentary by drawing our attention 
to the metaphor of Raymundo Mata's blindness and how it signals a shift in the terrain of "knowledge production" to unknown territory. Brennan's explanation rings true at this point: this unhomeliness for Ponce that allows for the invention of "unfixed [and] permeable" identities (232) is ironically an aesthetic exercise in perspective which, as suggested by the foregoing discussion, makes Apostol's fiction intelligible to metropolitan audiences in the global North. Ponce's view that The Revolution addresses Resil Mojares' call, in Waiting for Mariang Makiling: Essays in Philippine Cultural History, for a more representative national history that remains open to "the reality of many unaggregated, dispersed, and competing versions of community," which makes visible what "is rendered peripheral, subordinate, or invisible in the formation of the nation" (223), is unpersuasive. The peripheral in Waiting for Mariang Makiling pertains to "the local structures of belief and knowledge" (7), which are relegated to local, regional or provincial status in contradistinction to the national (308). As such, which narratives of belonging does The Revolution bring to fore against the hegemony of national discourse? It is unfortunate that Mojares' points are taken out of context. This (Apostol's) estranging perspective conceives of reading as in itself a political act but does so in a way that dismisses the relevance of content or, more problematically, any grounding on the social as if the reader is, in a misreading of Barthes, "without history, biography, psychology" (ImageMusic-Text 148). The dissociation from the social world is effected by Apostol's insistence on reading as a blank concept without recourse to its historical and material particularity. As San Juan points out, postcolonial criticism (i.e., Bhabha's) views its enunciation as "an uninterrupted process of performance... that elevates the 'language' metaphor to transcendental aprioristic status" (26). By not configuring the reader as a historical subject, Apostol's reader becomes an instrument in the author's self-writing often referred to as fictocriticism.

Brennan has critiqued this kind of writing that claims exemption from the political and the economic in disavowing mediation as a critical method in the analysis of texts since the text, as its proponents claim, is already the performance of the political. In line with his argument that a 
sociology of literature remains relevant in the study of form, Brennan notes that "this new textualism has, in one variant, found a voice also in 'fictocriticism,' where creative writing is seen as itself a theory, and where theory, in order to perform its political task fulfills itself in literature" ("Running and Dodging" 279). He explains that this discourse pronounces itself, echoing Benitez's criticism, "as immediately political-whose theory is a politics performed" which entails "the deliberate rejection of all correspondence to experience, evidence or proof" since it generates "new modalities of perception" ("Running and Dodging" 280). These maneuvers are evident in Apostol's self-conscious techniques, which, as mentioned, forestall any other interpretation apart from a formal analysis that gives way to pleasure. This formalism which neatly delivers a postcolonial reading of Philippine history accounts for Apostol's appeal for international readers, a relationship that bears traces of the manner in which literary critics assumed the role of native informant in authorizing knowledge production about the Third World in the First World in the 80s, which marked the transformation of the postcolonial into a purely textual category. Underscoring the significance of this moment, Simon Gikandi writes:

[o]nce the 'Third World' speech communities had changed, once the primary audience for cultural discourse was based outside the national state...the global had to be reinvented as a substitute for nationalism. It was during the same period that minority communities in the metropolitan centres were adopted as supplements, or even field sites, for the vanishing 'Third World' (646).

An appropriation from ethnography, the native informant represents the non-West in a language authorized by the metropolitan First World. This role is more recently carried out by the "self-marginalizing or self-consolidating" postcolonial in Anglophone countries whose representation of his or her country is "needed and foreclosed" (Spivak 6). As explained by Spivak,

[ $\mathrm{t}$ ] he postcolonial informant has little to say about the oppressed minorities in the decolonized nation as such... Yet the aura of identification with those distant objects of oppression clings to these informants as, again at best, 
they identify with the other racial and ethnic minorities in metropolitan space. At worst, they take advantage of the aura and play the native informant uncontaminated by disavowed involvement with the machinery of the production of knowledge... The continuous and varied product of this dissimulation is an 'other' or 'ground level activity', 'emergent discourses' for postmodernity, a kind of built-in critical moment (360-361).

As a migrant writer in the U.S. and trained in one of its foremost creative writing programs, Apostol thus speaks on behalf of Filipinos and their history. As a cultural broker, she posits that the narrative design in Insurrecto is in itself indicative of the Philippine postcolonial condition: "the structure of the book mirrors how I figured out the war, which is layers and layers of other voices and the Filipinos barely heard. In my view, that structurethe absence or layers of other voices, tells us something about the Filipino" (Soliman). The imperative on reading (recall Apostol's requirement for "smarter readers"), reduces the Filipino into a reader like herself, a cosmopolitan whose perspective is that of the "triumphalist self-declared hybrid" (Spivak 361). Thus, she can only address the Filipino as a foreclosure on reading. Consequently in Insurrecto, Magsalin's perturbations about reading and the author's intentions are emblematic of the Filipino's quandary:

[h] ow many times has she waded into someone else's history, say the mysteries of lemon soaps and Irish pubs in Daedalus's Dublin, or the Decembrists' plot in Dostoevsky's The Devils, or Gustave Flaubert's Revolution of 1848 in what turns out to be one of her favorite books, Sentimental Education, and she would know absolutely nothing about the scenes, the historical background that drives them, the confusing cultural details...and yet she dives in, to try and figure what it is the writer wishes to tell (103). 


\section{Works Cited}

Anderson, Benedict. Imagined Communities: Reflections on the Origin and Spread of Nationalism. Verso. 2003.

Apostol, Gina. Bibliolepsy: A Novel. U of Philippines P, 1997.

---. Gun Dealer's Daughter: A Novel. W.W. Norton. 2010.

---. Insurrecto: A Novel. Soho Press, 2018,

---. The Revolution According to Raymundo Mata. Anvil, 2009.

---. The Revolution According to Raymundo Mata. Soho Press, 2021.

---. “Bookslut Interview: Gun Dealers' Daughter”. Gina Apostol, 10 July 2012, ginaapostol.wordpress.com/2012/07/10/bookslut-interview-gun-dealers-daughter.

---. "Borges, Politics, and the Postcolonial." Los Angeles Review of Books, 18 August 2013, lareviewofbooks.org/article/borges-politics-and-the-postcolonial/. Accessed 9 August 2021.

---. 'Empire at the End of Time': a Stunningly Smart Review of Gun Dealers' Daughter from the L.A. Review of Books." Gina Apostol, 19 November 2012, ginaapostol.wordpress.com/2012/11/19/empire-at-the-end-of-time-a-stunningly-smart-review-of-gun-dealers-daughter-from-the-1-a-review-of-books/.

---. "Listen to Woman-Stirred Radio; Merry Gangemi is an entertaining host". Gina Apostol, 3 August 2012, ginaapostol.wordpress.com/2012/08/03/listen-towoman-stired-radio-merry-gangemi-is-an-entertaining-host-4-2/. Accessed 07 November 2021.

---. “Lovely Review of Gun Dealers' Daughter by Kerry McHugh on Shelf-Awareness.com". Gina Apostol, 13 July 2012, ginaapostol.wordpress. com/2012/07/13/review-of-gun-dealers-daughter-on-shelf-awareness-com/.

---. “My Borgesian Rizal.” Gina Apostol, 2 August 2014, ginaapostol.wordpress. com/2014/08/02/my-borgesian-rizal/. Accessed 9 August 2021.

---. "Nice Job of Research on The Revolution According to Raymundo Mata." Gina Apostol, 30 July 2012, ginaapostol.wordpress.com/2012/07/30/nice-job-of-research-on-the-revolution-according-to-raymundo-mata./.

---. "Reading Novels: A Novelist's View." Gina Apostol, 20 February 2014, ginaapostol.wordpress.com/2014/02/20/reading-novels-a-novelists-view/. Accessed 9 August 2021.

Ashcroft, Bill, Gareth Griffiths and Helen Tiffin. Post-Colonial Studies: The Key Concepts. Routledge, 2000.

Barthes, Roland. Image-Music-Text. Fontana Press, 1977.

Belen, Brian. “Gun Dealer's Daughter: Review.” Brain Drain. 8 July 2012, brianbelen. blogspot.com/2012/07/gun-dealers-daughter-review.html?m=1. Accessed 21 July 2021. 
Benitez, Christian. "Book review: Gina Apostol, Insurrecto: A Novel and Dominic Sy, A Natural History of Empires: Stories.” SARE, vol. 57, no. 2, December 2020, pp. 110-114, ResearchGate. doi:10.22452/sare.vol57no.2.13.

Benwell, Bethan and James Procter. Reading Across Worlds: Transnational Book Groups and The Reception of Difference. Palgrave Macmillan, 2015.

Boehmer, Elleke. "Differential Publics-Reading (in) the Postcolonial Novel." Cambridge Journal of Postcolonial Literary Inquiry, vol. 4, no. 1, January 2017, pp. 11-25. Cambridge UP. doi:10.1017/pli.2016.43.

Brennan, Timothy. At Home in the World: Cosmopolitan Now. Harvard UP, 1997.

---. "Cosmopolitans and Celebrities." Race and Class, vol. 31, no. 1, 1 July 1989, pp. 1-19. SAGE Journals. doi.org/10.1177/030639688903100102.

---. "Cosmo-Theory." The South Atlantic Quarterly, vol. 100, no. 3, Summer 2001, pp. 659-691. Project MUSE muse.jhu.edu/article/30717.

---. "Running and Dodging: The Rhetoric of Doubleness in Contemporary Theory". New Literary History, vol. 41, no. 2. Spring 2010, pp. 277-299. Project MUSE. doi: $10.1353 /$ nlh.2010.0012

Brouillette, Sarah. Postcolonial Writers in the Global Literary Marketplace. Palgrave, 2007.

Casanova, Pascale. The World Republic of Letters. Harvard UP, 2004.

Collins, Brian. "Empire at the End of Time: On Gina Apostol's Gun Dealer's Daughter”. Los Angeles Review of Books, 19 Nov. 2012, lareviewofbooks.org/ article/empire-at-the-end-of-time-on-gina-apostols-gun-dealers-daughter/. Accessed 13 June 2021.

De Guzman, Paul. “The Marginaliad: Reading Gina Apostol's The Revolution According to Raymundo Mata." Kritika Kultura 15, 2010, pp. 284-296, journals. ateneo.edu/ojs/index.php/kk/article/download/1456/1481.

Garces-Bascal, Myra. "Women Authors from Malaysia and the Philippines: Fraught Mother-Daughter Relationship and an Unlikely Friendship between a Female Translator and a Filmmaker". Gathering Books, 6 May 2019, gatheringbooks. org/2019/05/06/monday-reading-126/. Accessed 28 September 2021.

Genette, Gerard. Paratexts: Thresholds of Interpretation. Cambridge UP, 1997.

Ghosh, William. "The Formalist Genesis of 'Postcolonial' Reading: Brathwaithe, Bhabha, and A House for Mr. Biswas.” ELH Journal, vol. 84, no. 3, 2017, pp. 765-789. Project MUSE. doi:10.1353/elh.2017.0029.

Gikandi, Simon. "Globalization and the Claims of Postcoloniality." The South Atlantic Quarterly, vol. 100, no. 3, Summer 2001, pp. 627-658. Project MUSE.

Huggan, Graham. The Postcolonial Exotic: Marketing the Margins. Routledge, 2001. McGurl, Mark. The Program Era: Postwar Fiction and The Rise of Creative Writing. Harvard UP, 2009. 
Mc Hugh, Kerry. "Book Review: Gun Dealer's Daughter, By Gina Apostol.” Entomology of a Bookworm, 13 July 2012, www.entomologyofabookworm. com/2012/07/book-review-gun-dealers-daughter-by.html. Accessed 27 June 2021.

Mojares, Resil. Waiting for Mariang Makiling: Essays in Philippine Cultural History. Ateneo de Manila UP, 2002.

Murray, Sabina. "No Failure of Imagination: Gina Apostol on Revolution, Illusion, and Translation." LitHub, 16 Feb. 2021, lithub.com/no-failure-of-imagination-gina-apostol-on-revolution-illusion-and-translation/. Accessed 18 September 2021.

Nadal, Paul. "The Novel and Technologies of Empire: A Conversation with Gina Apostol." The Margins, 28 Feb. 2020, aaww.org/technologies-of-empire-gina-apostol/. Accessed 8 August 2021.

Ponce, Martin Joseph. Beyond the Nation: Diasporic Filipino Literature and Queer Reading. New York UP, 2012.

Robb, Simon. Fictocritical Sentences. 2001. U of Adelaide, PhD dissertation.

Said, Edward. Culture and Imperialism, Vintage Books, 1994.

San Juan Jr., Epifanio. Beyond Postcolonial Theory. Palgrave, 1998.

Soliman, Michelle. "History lesson from author Gina Apostol." Business World, 14 August 2019, www.bworldonline.com/history-lesson-from-author-ginaapostol/. Accessed 3 October 2021.

Spivak, Gayatri. A Critique of Postcolonial Reason: Toward the History of a Vanishing Present. Harvard UP, 1999.

Stack, Micah. "A Way to Poke Fun at Power: An Interview with Gina Apostol." Fiction Advocate, 2 Apr., 2019, www.fictionadvocate.com/2019/04/02/a-wayto-poke-at-power-an-interview-with-gina-apostol/. Accessed 28 September 2021. 